\title{
Members of the Month
}

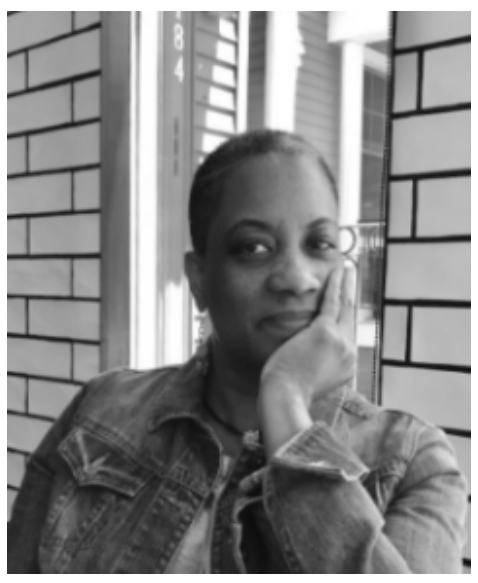

\section{JULIA JORDAN-ZACHERY \\ FEBRUARY MEMBER OF THE MONTH \\ University of North Carolina at Charlotte}

"I'm still not convinced that I neatly fit into APSA. But here I am. So why am I still here, too many years later for me to count (or willingly acknowledge)? It has to do with what happens in the "cracks" of APSA-in those small spaces where recognition occurs It's in those spaces where Julia, the Black woman, the human (and less so the political scientist) is recognized that encourages me to stay a member of APSA."

\section{Leonardo R. Arriola \\ MARCH MEMBER OF THE MONTH University of California, Berkeley}

"I joined APSA when I was a graduate student because I wanted to become part of an academic community that shared my research interests. Many of the people l've met at the annual meetings, either on panels or through section meetings, have since become collaborators, mentors, and friends."

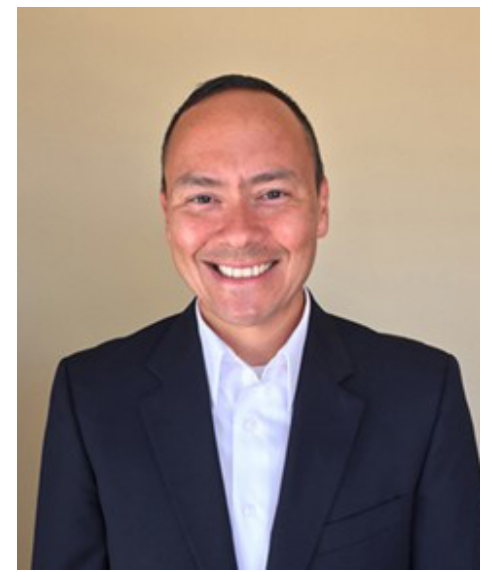

\section{Nadia E. Brown \\ APRIL MEMBER OF THE MONTH \\ Purdue University}

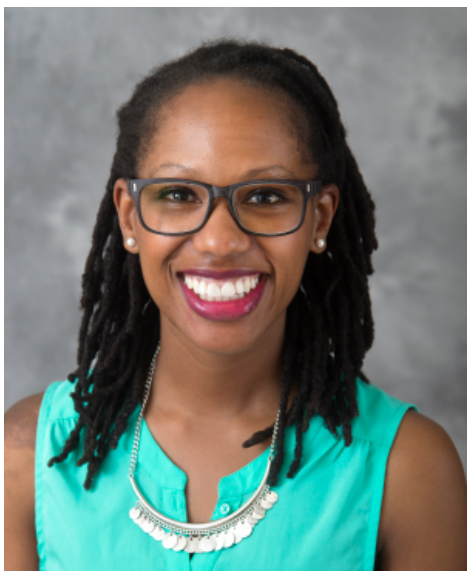

"The Ralph Bunche Summer Institute changed my life-this program is the reason why I am a political scientist, joined APSA, and am an active member. I credit my scholarly foundation to the exposure that I received at Bunche and its network for sustaining me in the profession. APSA's support of the program is invaluable for scholars like myself and has helped to transform the discipline into a more diverse and inclusive place in its over 30 years of existence."

The APSA Member of the Month program recognizes one member each month. Nominations for the award (including self-nominations) may be submitted by members and nonmembers of APSA. To submit your nomination visit our member of the month page online: www.apsanet.org/motm. 


\section{Achieving Diversity and Inclusion in Political Science}

\section{Diversity and Inclusion Programs}

The American Political Science Association has several major programs aimed at enhancing diversity within the discipline and identifying and aiding students and faculty from underrepresented backgrounds in the political science field. These programs include:

Ralph Bunche Summer Institute (RBSI) (Undergraduate Juniors)

The RBSI Program is an annual five-week program designed to introduce to the world of doctoral study in political science to those undergraduate students from under-represented racial/ethnic groups or those interested in broadening participation in political science and pursuing scholarship on issues affecting underrepresented groups or issues of tribal sovereignty and governance. Application deadline: January of each year. For more information, visit www.apsanet.org/rbsi.

APSA Minority Fellows Program (MFP) (Undergraduate Seniors or MA and PhD students) (Fall Cycle for seniors and MA Students, Spring Cycle for PhD students) MFP is a fellowship competition for those applying to graduate school, designed to increase the number of individuals from under-represented backgrounds with PhD's in political science. Application deadline: October and March of each year. For more information, visit www.apsanet.org/mfp.

Minority Student Recruitment Program (MSRP) (Undergraduates and Departmental members) The MSRP was created to identify undergraduate students from under-represented backgrounds who are interested in, or show potential for, graduate study and, ultimately, to help further diversify the political science profession. For more information, visit www.apsanet.org/msrp.

\section{APSA Mentoring Program}

The Mentoring Program connects undergraduate, graduate students, and junior faculty to experienced and senior members of the profession for professional development mentoring. APSA membership is required for mentors. To request a mentor or be a mentor, visit www.apsanet.org/mentor.

\section{APSA Status Committees}

APSA Status Committees develop and promote agendas and activities concerning the professional development and current status of under-represented communities within the political science discipline. For a listing of all APSA status committees, visit www.apsanet.org/status-committees.

For more information on all Diversity and Inclusion Programs, visit us online at www.apsanet.org/ diversityprograms. Please contact Kimberly Mealy, PhD, Senior Director of Diversity and Inclusion Programs with any questions: kmealy@apsanet.org.

To contribute to an APSA Fund, such as the Ralph Bunche Endowment Fund or the Hanes Walton Jr. Fund, visit us at www.apsanet.org/donate. 